Hum Gene Ther. 2008 May ; 19(5): 443-450. doi:10.1089/hum.2008.045.

\title{
Aptamers in immunotherapy
}

\author{
Claudia M. Dollins, Smita Nair, and Bruce A. Sullenger ${ }^{*}$ \\ Department of Surgery and Duke Translational Institute, Duke University Medical Center, \\ Durham, NC 27710
}

\section{Introduction}

Numerous nucleic acid ligands, also termed decoys or aptamer, have been developed during the past 20 years that can bind to and inhibit the activity of many proteins. The concept that nucleic acid ligands could modulate the activity of proteins emerged from basic science studies of viruses and early work in the field of gene therapy. In the 1980s, research on HIV and adenovirus discovered that these viruses encode a number of small structured RNAs that bind to viral or cellular proteins with high affinity and specificity. For example the human immunodeficiency virus has evolved a short, structured RNA ligand the HIV TAR element that binds to the viral protein tat as well as the cellular protein cyclin T1 to control viral gene expression and replication. Similarly adenovirus has evolved a short structured RNA aptamer, termed VA-RNA, to inhibit interferon induced PKR activity and thus block one of the mammalian cell's antiviral strategies (O'Malley et al., 1986; Burgert et al., 2002). The observation that viruses utilize RNA ligands for their ends suggested to those working in the field of gene therapy in the late 1980s that RNA ligands might also be useful for therapeutic ends.

The first study performed to determine if an RNA aptamer could be utilized to inhibit the activity of a pathogenic protein was published in 1990. This groundbreaking work demonstrated that the TAR aptamer evolved by HIV to recruit viral and cellular proteins to viral transcripts could be turned against the virus to inhibit HIV replication (Sullenger et al., 1990). CD4+ T-Cells containing the TAR aptamer were shown to be highly resistant to viral replication and cytotoxicity (Sullenger et al., 1990). Thus these studies demonstrated for the first time that RNA ligands could be utilized as therapeutic agents to directly bind and inhibit the activity of clinically relevant proteins. This approach to HIV gene therapy is still being explored today by Rossi and colleagues (Li et al., 2005; Anderson et al., 2007).

In the same year as the discovery that RNA ligands represent a new class of therapeutic agent, Tuerk and Gold (Tuerk and Gold, 1990) and Ellington and Szostak (Ellington and Szostak, 1990) demonstrated that large libraries of RNAs could be screened in vitro for RNA ligands that bind T4 DNA polymerase and a variety of organic dye respectively. This in vitro selection process, was termed SELEX (systematic evolution of ligands by exponential enrichment) by Tuerk and Gold (Tuerk and Gold, 1990) and the resulting RNA ligands were given the name aptamers by Ellington and Szostak (Ellington and Szostak, 1990). This approach has been widely used during the past two decades to generate RNA ligands to many proteins (Reviewed in Nimjee et al., 2005).

The focus on this review is on aptamers relevant for the treatment of cancer, particularly aptamers targeting proteins that could be relevant to tumor immunotherapy. Tumor cells vary from healthy cells quantitatively and qualitatively in their protein repertoire. These

\footnotetext{
`To whom correspondence should be addressed. (bruce.sullenger@ duke.edu).
} 
cells differ qualitatively due to their inherent genetic instability, which is brought about by defects in cell cycle or factors involved in replication of genetic information. This lack of control leads to the expression of a variety of defective cell products and protein mutations in their amino acid sequence. One such example is the receptor tyrosine kinase (RTK) RET. A point mutation (C634Y) has been shown to produce a constitutively active form of the receptor and has been implicated in the development multiple endocrine neoplasia (MEN) type 2A and 2B syndromes and familial medullary thyroid carcinoma (Pestourie et al., 2006). Aptamers to these targets have been developed through SELEX targeting purified protein constructs as well as cells expressing the protein target (Cerchia et al., 2005; Pestourie et al., 2006). Though these aptamers were shown to bind and inhibit the function of RET C634Y, and revert morphological changes in the morphology of fibroblast (NIH3T3) transfected with the mutant receptor, the compound's in vivo function remains to be determined.

Aside from the differences in quality, the quantity of protein expressed can also differ vastly in cancerous cells: expression can be upregulated or de novo induced. Together with qualitatively different proteins, these overexpressed proteins are referred to as tumor markers. These proteins can be used to detect the presence of cancerous tissue, directly affect tumor progression through manipulation of tumor marker function, or deliver therapeutic agents to the tumor. Therefore, many aptamers have been developed that target tumor markers. These include aptamers targeting MUC-1 (CD227) (Ferreira et al., 2006), prostate specific membrane antigen (PSMA) (Lupold et al., 2002), human epidermal growth factor receptor-3 (HER3) (Chen et al., 2003), and tenascin-c (Hicke et al., 2001; Daniels et al., 2003), liver carcinoma cells (Shangguan et al., 2008b), and protein tyrosine kinase 7 (PTK7) (Shangguan et al., 2008a) (Table 1). Most of these aptamers have or will be used for the detection of cancerous cells (PSMA, MUC-1, tenascin-c, PTK7, liver carcinoma) (Chu et al., 2006b; Ferreira et al., 2006; Hicke et al., 2006; Borbas et al., 2007; Smith et al., 2007; Shangguan et al., 2008a; Shangguan et al., 2008b), or as more recently as targeting moiety for the tumor specific delivery of other therapeutic agents including radioisotopes (PSMA) (Farokhzad et al., 2006; Borbas et al., 2007), toxins (PSMA) (Chu et al., 2006a), or siRNA (PSMA) (Chu et al., 2006c; McNamara et al., 2006).

To evaluate the potential usefulness of other receptor-targeting aptamers (such as MUC-1) for the delivery of intracellularly acting therapeutics (such as siRNAs), each receptor will have to be individually validated, as there are vast differences in mechanism for receptor internalization. Internalization may be a function of receptor turnover or could also be activation dependent. This can potentially result in large differences in receptor-mediated uptake efficiency, that will affect the amount of intracellular therapeutic delivered. An additional layer of complexity is added, as the therapeutically necessary amount of intracellularly acting compound to be delivered may differ widely. Only one of the tumor marker specific aptamers above mentioned has been demonstrated to have antagonistic activity (HER3) (Chen et al., 2003). This aptamer inhibits the growth of breast carcinoma cell line MCF 7. Unfortunately, its therapeutic potential is limited by its susceptibility to nuclease degradation as it is composed of natural RNA.

\section{Aptamers for the modulation of immune responses}

Cancer immunotherapy is based on the observation that tumor cells vary from healthy cells quantitatively and qualitatively in their protein (and potential antigen) repertoire. Cells of the immune system can in principle recognize unique tumor markers as antigen and they are therefore often referred to as tumor-associated antigen. In an ideal scenario, the generated response would be sufficient to destroy the tumor and indeed this is sometimes the case in the very early stages of tumor onset. Unfortunately, the strength of this type of response is usually weak and worse yet, tumors develop mechanisms over time that lead to evasion of 
immune recognition. These mechanisms include the expression of inhibitory ligands to induce down-regulation of immune function through negative co-stimulation (Dong et al., 2002; Chen, 2004).

The modulation and particularly the enhancement of tumor immune responses is of great therapeutic interest in the context of tumor immunotherapy. One approach has the potential to block undesired immune down-regulation to enhance therapeutic efficacy; another is to engage stimulatory signals. Antibodies, immunological receptors, cytokines, and chemokines have been targeted primarily through the development of antibodies or soluble version of receptor ligands or recombinant cytokines. Thus far, only few aptamers has been developed targeting immune modulatory proteins. Most of these were developed to inhibit immune responses and intended for application for the treatment of autoimmune diseases rather than the treatment of cancer by enhancing anti-tumor immune responses.

\section{Antibodies}

The first immunological molecules for which aptamers were isolated were antibodies (Table 2). Early work by Tsai, et al. targeted polyclonal antibodies raised in rabbits against a peptide portion of the bacteriophage T7 gene 10 protein (g10) (Tsai et al., 1992). Though the antibodies naturally interacted with g10, the isolated RNA antibodies were able to compete for antibody binding. Similarly, the approach was also extended to sera obtained from patients with the autoimmune disease systemic lupus erythematosus (SLE) (Tsai and Keene, 1993). This study isolated aptamers that contained a motif found in the U1 small nuclear RNA and was able to compete for autoantibody binding to U1 contained in the patient serum. These experiments were among the first to demonstrate the capacity of SELEX to isolate RNAs to non-nucleotide binding proteins and the first targeting immunological molecules. Additional studies published by Doudna, et al. (Doudna et al., 1995) as well as Lee, et. al. (Lee and Sullenger, 1996) isolated aptamers to monoclonal antibodies, including an antibody specific to the human insulin receptor, which binds to a major immunogenetic epitope. The generated aptamers block the interaction of the antibody with the insulin receptor and ameliorate the generated autoimmune response. SELEX against a monoclonal myasthenic antibody also generated a decoy, capable of blocking the interaction between the antibody antigen, the human acetylcholine receptor, and the antibody (Lee and Sullenger, 1997; Hwang and Lee, 2002). This example concludes the list of aptamers targeting the antigen binding sites of antibodies. An aptamer developed against human IgE, however, was intended to block the interaction of the antibody to its receptor, Fce Receptor I, rather than its antigen. The aptamer blocks the pathologic interaction of overexpressed IgE with the receptor in vitro, as is the case in allergic diseases such as allergies and asthma (Wiegand et al., 1996). Furthermore, this aptamer has been used as detection probes in atomic force microscopy (AFM) detection studies of IgE (Lin et al., 2006) as well as in microarrays (Cho et al., 2006).

\section{Cytokines}

Cytokines and chemokines are proteins that affect the growth, proliferation and function of immune effector cells of the innate and adaptive immune system. They play a vital role in the regulation of the magnitude and duration of immune responses. This class of proteins can function either in an agonistic or antagonistic manner.

IFN $\gamma$ is a member of the interferon family of cytokines. This immune stimulatory cytokine is secreted by activated lymphocytes, dendritic cells, and NK cells. Its function includes the enhancement of immune cell activity leading to increased anti-tumor responses. The presence of IFN $\gamma$ can therefore be beneficial for the treatment of tumors (Ikeda et al., 2002). However, it has also been involved in the development of autoimmune diseases (Kubik et 
al., 1997). An aptamer developed to human IFN $\gamma$ blocks binding of the cytokine to its receptor and could potentially be used for the treatment of inflammatory diseases (Kubik et al., 1997) (Table 3).

Oncostatin M is a member of the interleukin 6 cytokine family. Just as IFN $\gamma$, this cytokine also has proinflammatory function and can therefore enhance tumor immune responses but also aggravate autoimmune disease. The developed aptamer agonist has demonstrated the ability to block oncostatin-M receptor binding and downstream signaling event in vitro (Rhodes et al., 2000).

Transforming growth factor $\beta 1$ and 2 (TGF $\beta 1 \&$ TGF $\beta 2$ ) can induce cell growth or apoptosis and their inhibition has been shown to be useful for cancer therapy. Antagonistic aptamers to both targets have been developed (McCauley et al., 2006; Kang et al., 2008), though their effect on in vivo tumor growth remains to be determined.

\section{Chemokines}

Chemokines are agents that can induce cellular chemotaxis and thereby act as proinflammatory agents (Table 3). MCP-1 is an example of such a chemoattractant. An aptamer agonist can block chemokine function and could reduce autoimmune responses in a therapeutic setting. Another aptamer targeting a chemokine CXCL-10 (Rhodes et al., 2001) was developed to elucidate the biological function CXCL-10 (Marro et al., 2005). The antagonistic aptamer can block CXCL10 induced signaling, which may or may not be useful in the treatment of cancer since studies have shown that CXCL-10 can take on juxtaposing roles in cancer development as it can promote as well as diminish tumor growth.

Another chemokine, CCL1 affects the migration of monocytes and lymphocytes and has therefore potential to enhance autoimmunity as well as tumor immune responses. The antagonistic aptamer developed could be used as a tool to elucidate the chemokine's function in disease progression and determine the therapeutic potential of this target (Marro et al., 2006).

\section{Adhesion molecules}

Adhesion molecules are an integral part of tumorigenesis in that they allow for cellular migration through cell-to-cell contact. This can facilitate the spread of cancers. Metastasis development occurs if tumor cells adhere to distal tissues via adhesion molecules. Such molecules include the vascular cell adhesion molecule-1 (VCAM-1) (Chauveau et al., 2007), L-Selectin (Hicke et al., 1996), P-Selectin (Jenison et al., 1998), as well as the lectin Sialyl Lewis X (Jeong et al., 2001). Treatment with antagonists to these adhesion molecules could therefore inhibit the development of metastasis. Aptamers specific to these targets have been developed. The ability to block cellular adhesion in vitro has been demonstrated for the Pselectin (Jenison et al., 1998) and Sialyl Lewis X aptamers (Jeong et al., 2001), whereas the function of the L-Selectin aptamer has been validated in vivo (Hicke et al., 1996) (Table 4). The aptamer was capable of blocking human PBMC adhesion in a xenogeneic murine model. For cancer treatment, adhesion molecules are a double-edged sword: Though adhesion molecules are involved in the spread of cancers through the formation of metastasis, they also enhance extravasation of monocytes and macrophages into the tumor milieu to inhibit tumor growth. This dual role is reflected in the fact that the expression of selectins in patients has been correlated with tumor-progression, even though local tumor growth in selectin-deficient mice is enhanced (Borsig et al., 2001; Borsig et al., 2002; Borsig, 2004). 


\section{Costimulatory receptors}

Antigen stimulation is not the only component in T cell activation. T cells also express other types of receptors, called costimulatory molecules that provide important secondary signals to determine the outcome of antigen encounter. The importance of costimulatory signaling is outlined in the "two-signal hypothesis". According to the two-signal hypothesis, optimal T cell activation requires not only the presence of antigen but also an additional signal in form of costimulation (Sharpe and Freeman, 2002). As the name implies, this hypothesis states that two signals are needed to activate $\mathrm{T}$ cell responses. Signal one involves the interaction of the $\mathrm{T}$ cell receptor with a specific antigen presented via the major histocompatability complex (MHC). The antigen dependent stimulation alone is insufficient for activation, so that the $\mathrm{T}$ cell becomes unresponsive or tolerant in the absence of a costimulatory signal. However, in the presence of a signal through the costimulatory molecules on the surface of the APC, T cells are activated.

Though this hypothesis emphasizes the importance of costimulation, it is really an oversimplification of the $\mathrm{T}$ cell activation process since the strength of the primary signal produced by antigen varies. Indeed, a "strong" (optimal) first signal through the interaction of T cell receptor and MHC presented antigen is often sufficient to activate T cells. The secondary signal becomes more important in the presence of "weaker" primary signals (suboptimal) and is conveyed through receptors expressed on the surface of T cells.

In addition to positive costimulation, $\mathrm{T}$ lymphocytes and antigen presenting cells also interact through coinhibitory interactions and are capable of downregulating the $\mathrm{T}$ cell response. Positive signals are important for $\mathrm{T}$ lymphocyte activation, while negative signals lead to inhibition of activated T lymphocytes. The presence of these two types of costimulation regulates the degree and duration of the immune response. Most costimulatory receptors and ligands are members of the B7/CD28 superfamily and the tumor necrosis factor receptor (TNFR) family.

One such member of the tumor necrosis factor receptor (TNFR) member is the receptor activator of NFKB (RANK). Receptor signaling leads to osteoclast differentiation and is implicated in the development of bone malignancies as well as enhancement of the progression of rheumatoid arthritis (RA). An antagonistic agents therefore has the potential to treat both diseases. Unfortunately, developed aptamers antagonist bound to other TNF receptor family members that contained a common structural motif (Mori et al., 2004) - not the binding ligand site of the receptor and therefore does not act as receptor antagonist.

The B7/CD28 superfamily of proteins in named for its most prominent members B71/2 and CD28. The interaction between two receptors, CTLA-4 and CD28, and their shared ligands B7.1 and B7.2 is particularly well characterized. The ligands are expressed on dendritic cells, B cells and monocytes. Though B7.1 and B7.2 are capable of binding both CTLA-4 and CD28, with opposite consequences: CTLA-4 results in inhibition, whereas CD28 is a costimulatory receptor. Our laboratory in collaboration with the laboratory of Dr. Eli Gilboa has demonstrated that an antagonistic aptamer targeting the inhibitory receptor CTLA-4 is capable of enhancing the efficacy of DC based tumor immunotherapy in a murine mouse model (Santulli-Marotto et al., 2003). The potency of this aptamer antagonist was enhanced by arraying the aptamer on a complementary DNA scaffold to increase its valency. This allows interaction with multiple CTLA-4 receptors simultaneously. The multimerized aptamer was indeed shown to block CTLA-4 function in vitro as well as in vivo in a tumor immunotherapy model.

CD4 is a member of the immunoglobulin superfamily and a cell surface receptor expressed on a variety of immunological cells, most notably a subset of $\mathrm{T}$ cells referred to as $\mathrm{T}$ helper 
cells. This costimulatory receptor acts to enhance the primary immune response conveyed by the T cell receptor. In 1998, two aptamers were described that were specific to the human and rat homolog that bind the receptor with high affinity (Kraus et al., 1998). The ligand targeting the rat receptor was shown to inhibit CD4 function in vitro, whereas the ligand specific to the human receptor is used as a targeting moiety to fluorescently label CD4+ cells (Davis et al., 1998) and deliver cargo (including siRNA) to cells expressing the receptor (Guo et al., 2005).

The biological role of the transforming growth factor $\beta$ receptor III (TGF $\beta$ RIII) remains somewhat poorly understood. It has been demonstrated, however, that downregulation of receptor levels correlates with breast cancer progression. Moreover, restoration of expression of TGF $\beta$ RIII reduced tumor invasiveness and formation of metastasis. An aptamer developed to this target actually inhibits the interaction of TGFßRIII with its ligand TGF 32 and would most likely not be useful for the treatment of cancer (Ohuchi et al., 2006). However, it may be useful in elucidating the role of TGF $\beta$ RIII in cancer development.

Lastly, we would like to discuss an aptamer agonist developed to the costimulatory receptor 4-1BB (McNamara et al., 2008). This project aimed at developing a receptor agonist rather than an antagonist. Previously, bivalent antibodies and multivalent version of natural ligands and small molecules have been shown to induce tumor necrosis factor receptor function. Dimerization of the generated 4-1BB aptamer by base-pairing of a single stranded extended region similarly lead to the creation of an agonistic compound that could enhance $\mathrm{T}$ cell proliferation in vitro and lead to tumor rejection when administered in vivo.

Another class of immune-stimulatory receptors has been gaining attention recently: Toll-like receptors (TLRs) recognize various microbial and viral products, leading to activation of innate immune responses. Some of these receptors are capable of recognizing nucleic acid ligands such as double - (TLR 3) or single stranded RNA (TLR8) and unmethylated DNA (TLR 9) (for review see (Takeda et al., 2003)). Aptamers to a portion of the ectodomain of TLR3 were developed (Watanabe et al., 2006). Though the aptamers could bind to a purified construct, they were not capable of affecting the function of HEK293 cells transfected with TLR3.

\section{Conclusion}

Many RNA aptamers have been developed targeting proteins involved in immunological processes. Most of these aptamers were intended for application in protein detection, imaging or therapeutic dampening of immune responses as relevant for the treatment of autoimmune disease, rather than for tumor immunotherapy through enhancement of tumor immune responses. However, our lab has demonstrated the feasibility of generating aptamers to receptors that have immune regulatory or costimulatory functionas demonstrated by - (Santulli- Marotto et al., 2003; McNamara et al., 2008), which utilized aptamers for the enhancement of tumor immune responses in murine tumor immunotherapy models.

This review sought to demonstrate the possibility, potential and need for investigating aptamers capable of stimulating immune responses and to generate interest in aptamers for the treatment of cancer. Given the recent progress in the aptamer-immunotherapy field and the recent observations about the interaction between siRNAs and the innate immune system, we believe that understanding and being able to manipulate the interplay between nucleic acid ligands and the immune system will be essential for therapeutic oligonucleotides to fulfill their promise as molecular therapeutics. 


\section{References}

ANDERSON J, LI MJ, PALMER B, REMLING L, LI S, YAM P, YEE JK, ROSSI J, ZAIA J, AKKINA R. Safety and efficacy of a lentiviral vector containing three anti-HIV genes--CCR5 ribozyme, tat-rev siRNA, and TAR decoy--in SCID-hu mouse-derived T cells. Mol Ther. 2007; 15:1182-1188. [PubMed: 17406343]

BORBAS KE, FERREIRA CS, PERKINS A, BRUCE JI, MISSAILIDIS S. Design and synthesis of mono- and multimeric targeted radiopharmaceuticals based on novel cyclen ligands coupled to antiMUC1 aptamers for the diagnostic imaging and targeted radiotherapy of cancer. Bioconjug Chem. 2007; 18:1205-1212. [PubMed: 17583928]

BORSIG L. Selectins facilitate carcinoma metastasis and heparin can prevent them. News Physiol Sci. 2004; 19:16-21. [PubMed: 14739398]

BORSIG L, WONG R, FERAMISCO J, NADEAU DR, VARKI NM, VARKI A. Heparin and cancer revisited: mechanistic connections involving platelets, P-selectin, carcinoma mucins, and tumor metastasis. Proc Natl Acad Sci U S A. 2001; 98:3352-3357. [PubMed: 11248082]

BORSIG L, WONG R, HYNES RO, VARKI NM, VARKI A. Synergistic effects of L- and P-selectin in facilitating tumor metastasis can involve non-mucin ligands and implicate leukocytes as enhancers of metastasis. Proc Natl Acad Sci U S A. 2002; 99:2193-2198. [PubMed: 11854515]

BURGERT HG, RUZSICS Z, OBERMEIER S, HILGENDORF A, WINDHEIM M, ELSING A. Subversion of host defense mechanisms by adenoviruses. Curr Top Microbiol Immunol. 2002; 269:273-318. [PubMed: 12224514]

CERCHIA L, DUCONGE F, PESTOURIE C, BOULAY J, AISSOUNI Y, GOMBERT K, TAVITIAN B, DE FRANCISCIS V, LIBRI D. Neutralizing aptamers from whole-cell SELEX inhibit the RET receptor tyrosine kinase. PLoS Biol. 2005; 3:e123. [PubMed: 15769183]

CHAUVEAU F, AISSOUNI Y, HAMM J, BOUTIN H, LIBRI D, DUCONGE F, TAVITIAN B. Binding of an aptamer to the N-terminal fragment of VCAM-1. Bioorg Med Chem Lett. 2007; 17:6119-6122. [PubMed: 17905582]

CHEN CH, CHERNIS GA, HOANG VQ, LANDGRAF R. Inhibition of heregulin signaling by an aptamer that preferentially binds to the oligomeric form of human epidermal growth factor receptor-3. Proc Natl Acad Sci U S A. 2003; 100:9226-9231. [PubMed: 12874383]

CHEN L. Co-inhibitory molecules of the B7-CD28 family in the control of T-cell immunity. Nat Rev Immunol. 2004; 4:336-347. [PubMed: 15122199]

CHO EJ, COLLETT JR, SZAFRANSKA AE, ELLINGTON AD. Optimization of aptamer microarray technology for multiple protein targets. Anal Chim Acta. 2006; 564:82-90. [PubMed: 17723365]

CHU TC, MARKS JW 3RD, LAVERY LA, FAULKNER S, ROSENBLUM MG, ELLINGTON AD, LEVY M. Aptamer:toxin conjugates that specifically target prostate tumor cells. Cancer Res. 2006a; 66:5989-5992. [PubMed: 16778167]

CHU TC, SHIEH F, LAVERY LA, LEVY M, RICHARDS-KORTUM R, KORGEL BA, ELLINGTON AD. Labeling tumor cells with fluorescent nanocrystal-aptamer bioconjugates. Biosens Bioelectron. 2006b; 21:1859- 1866. [PubMed: 16495043]

CHU TC, TWU KY, ELLINGTON AD, LEVY M. Aptamer mediated siRNA delivery. Nucleic Acids Res. 2006c; 34:e73. [PubMed: 16740739]

DANIELS DA, CHEN H, HICKE BJ, SWIDEREK KM, GOLD L. A tenascin-C aptamer identified by tumor cell SELEX: systematic evolution of ligands by exponential enrichment. Proc Natl Acad Sci U S A. 2003; 100:15416-15421. [PubMed: 14676325]

DAVIS KA, LIN Y, ABRAMS B, JAYASENA SD. Staining of cell surface human CD4 with 2' -Fpyrimidine-containing RNA aptamers for flow cytometry. Nucleic Acids Res. 1998; 26:39153924. [PubMed: 9705498]

DONG H, STROME SE, SALOMAO DR, TAMURA H, HIRANO F, FLIES DB, ROCHE PC, LU J, ZHU G, TAMADA K, LENNON VA, CELIS E, CHEN L. Tumor-associated B7-H1 promotes Tcell apoptosis: a potential mechanism of immune evasion. Nat Med. 2002; 8:793-800. [PubMed: 12091876] 
DOUDNA JA, CECH TR, SULLENGER BA. Selection of an RNA molecule that mimics a major autoantigenic epitope of human insulin receptor. Proc Natl Acad Sci U S A. 1995; 92:2355-2359. [PubMed: 7534420]

ELLINGTON AD, SZOSTAK JW. In vitro selection of RNA molecules that bind specific ligands. Nature. 1990; 346:818-822. [PubMed: 1697402]

FAROKHZAD OC, CHENG J, TEPLY BA, SHERIFI I, JON S, KANTOFF PW, RICHIE JP, LANGER R. Targeted nanoparticle-aptamer bioconjugates for cancer chemotherapy in vivo. Proc Natl Acad Sci U S A. 2006; 103:6315-6320. [PubMed: 16606824]

FAROKHZAD OC, JON S, KHADEMHOSSEINI A, TRAN TN, LAVAN DA, LANGER R. Nanoparticle-aptamer bioconjugates: a new approach for targeting prostate cancer cells. Cancer Res. 2004; 64:7668-7672. [PubMed: 15520166]

FERREIRA CS, MATTHEWS CS, MISSAILIDIS S. DNA aptamers that bind to MUC1 tumour marker: design and characterization of MUC1-binding single-stranded DNA aptamers. Tumour Biol. 2006; 27:289-301. [PubMed: 17033199]

GU F, ZHANG L, TEPLY BA, MANN N, WANG A, RADOVIC-MORENO AF, LANGER R, FAROKHZAD OC. Precise engineering of targeted nanoparticles by using self-assembled biointegrated block copolymers. Proc Natl Acad Sci U S A. 2008; 105:2586-2591. [PubMed: 18272481]

GUO S, TSCHAMMER N, MOHAMMED S, GUO P. Specific delivery of therapeutic RNAs to cancer cells via the dimerization mechanism of phi29 motor pRNA. Hum Gene Ther. 2005; 16:1097-1109. [PubMed: 16149908]

HICKE BJ, MARION C, CHANG YF, GOULD T, LYNOTT CK, PARMA D, SCHMIDT PG, WARREN S. Tenascin-C aptamers are generated using tumor cells and purified protein. J Biol Chem. 2001; 276:48644-48654. [PubMed: 11590140]

HICKE BJ, STEPHENS AW, GOULD T, CHANG YF, LYNOTT CK, HEIL J, BORKOWSKI S, HILGER CS, COOK G, WARREN S, SCHMIDT PG. Tumor targeting by an aptamer. J Nucl Med. 2006; 47:668-678. [PubMed: 16595502]

HICKE BJ, WATSON SR, KOENIG A, LYNOTT CK, BARGATZE RF, CHANG YF, RINGQUIST S, MOON-MCDERMOTT L, JENNINGS S, FITZWATER T, HAN HL, VARKI N, ALBINANA I, WILLIS MC, VARKI A, PARMA D. DNA aptamers block L-selectin function in vivo. Inhibition of human lymphocyte trafficking in SCID mice. J Clin Invest. 1996; 98:2688-2692. [PubMed: 8981912]

HWANG B, LEE SW. Improvement of RNA aptamer activity against myasthenic autoantibodies by extended sequence selection. Biochem Biophys Res Commun. 2002; 290:656-662. [PubMed: 11785949]

IKEDA H, OLD LJ, SCHREIBER RD. The roles of IFN gamma in protection against tumor development and cancer immunoediting. Cytokine Growth Factor Rev. 2002; 13:95-109. [PubMed: 11900986]

JENISON RD, JENNINGS SD, WALKER DW, BARGATZE RF, PARMA D. Oligonucleotide inhibitors of P-selectin-dependent neutrophil-platelet adhesion. Antisense Nucleic Acid Drug Dev. 1998; 8:265-279. [PubMed: 9743465]

JEONG S, EOM T, KIM S, LEE S, YU J. In vitro selection of the RNA aptamer against the Sialyl Lewis X and its inhibition of the cell adhesion. Biochem Biophys Res Commun. 2001; 281:237243. [PubMed: 11178986]

KANG J, LEE MS, COPLAND JA 3RD, LUXON BA, GORENSTEIN DG. Combinatorial selection of a single stranded DNA thioaptamer targeting TGF-beta1 protein. Bioorg Med Chem Lett. 2008; 18:1835-1839. [PubMed: 18294846]

KRAUS E, JAMES W, BARCLAY AN. Cutting edge: novel RNA ligands able to bind CD4 antigen and inhibit CD4+ T lymphocyte function. J Immunol. 1998; 160:5209-5212. [PubMed: 9605115]

KUBIK MF, BELL C, FITZWATER T, WATSON SR, TASSET DM. Isolation and characterization of $2^{\prime}$-fluoro-, $2^{\prime}$-amino-, and $2^{\prime}$-fluoro-/amino-modified RNA ligands to human IFN-gamma that inhibit receptor binding. J Immunol. 1997; 159:259-267. [PubMed: 9200462] 
LEE SW, SULLENGER BA. Isolation of a nuclease-resistant decoy RNA that selectively blocks autoantibody binding to insulin receptors on human lymphocytes. J Exp Med. 1996; 184:315-324. [PubMed: 8760785]

LEE SW, SULLENGER BA. Isolation of a nuclease-resistant decoy RNA that can protect human acetylcholine receptors from myasthenic antibodies. Nat Biotechnol. 1997; 15:41-45. [PubMed: 9035104]

LI MJ, KIM J, LI S, ZAIA J, YEE JK, ANDERSON J, AKKINA R, ROSSI JJ. Long-term inhibition of HIV-1 infection in primary hematopoietic cells by lentiviral vector delivery of a triple combination of anti- HIV shRNA, anti-CCR5 ribozyme, and a nucleolar-localizing TAR decoy. Mol Ther. 2005; 12:900-909. [PubMed: 16115802]

LIN L, WANG H, LIU Y, YAN H, LINDSAY S. Recognition imaging with a DNA aptamer. Biophys J. 2006; 90:4236-4238. [PubMed: 16513776]

LUPOLD SE, HICKE BJ, LIN Y, COFFEY DS. Identification and characterization of nucleasestabilized RNA molecules that bind human prostate cancer cells via the prostate-specific membrane antigen. Cancer Res. 2002; 62:4029- 4033. [PubMed: 12124337]

MARRO ML, DANIELS DA, ANDREW DP, CHAPMAN TD, GEARING KL. In vitro selection of RNA aptamers that block CCL1 chemokine function. Biochem Biophys Res Commun. 2006; 349:270-276. [PubMed: 16930539]

MARRO ML, DANIELS DA, MCNAMEE A, ANDREW DP, CHAPMAN TD, JIANG MS, WU Z, SMITH JL, PATEL KK, GEARING KL. Identification of potent and selective RNA antagonists of the IFN-gamma-inducible CXCL10 chemokine. Biochemistry. 2005; 44:8449-8460. [PubMed: 15938634]

MCCAULEY TG, KURZ JC, MERLINO PG, LEWIS SD, GILBERT M, EPSTEIN DM, MARSH HN. Pharmacologic and pharmacokinetic assessment of anti-TGFbeta2 aptamers in rabbit plasma and aqueous humor. Pharm Res. 2006; 23:303-311. [PubMed: 16411148]

MCNAMARA JO 2ND, ANDRECHEK ER, WANG Y, VILES KD, REMPEL RE, GILBOA E, SULLENGER BA, GIANGRANDE PH. Cell type-specific delivery of siRNAs with aptamersiRNA chimeras. Nat Biotechnol. 2006; 24:1005-1015. [PubMed: 16823371]

MCNAMARA JO, KOLONIAS D, PASTOR F, MITTLER RS, CHEN L, GIANGRANDE PH, SULLENGER B, GILBOA E. Multivalent 4-1BB binding aptamers costimulate CD8+ T cells and inhibit tumor growth in mice. J Clin Invest. 2008; 118:376-386. [PubMed: 18060045]

MORI T, OGURO A, OHTSU T, NAKAMURA Y. RNA aptamers selected against the receptor activator of NF-kappaB acquire general affinity to proteins of the tumor necrosis factor receptor family. Nucleic Acids Res. 2004; 32:6120- 6128. [PubMed: 15562003]

NIMJEE SM, RUSCONI CP, SULLENGER BA. Aptamers: an emerging class of therapeutics. Annu Rev Med. 2005; 56:555-583. [PubMed: 15660527]

O'MALLEY RP, MARIANO TM, SIEKIERKA J, MATHEWS MB. A mechanism for the control of protein synthesis by adenovirus VA RNAI. Cell. 1986; 44:391-400. [PubMed: 3943131]

OHUCHI SP, OHTSU T, NAKAMURA Y. Selection of RNA aptamers against recombinant transforming growth factor-beta type III receptor displayed on cell surface. Biochimie. 2006; 88:897-904. [PubMed: 16540230]

PESTOURIE C, CERCHIA L, GOMBERT K, AISSOUNI Y, BOULAY J, DE FRANCISCIS V, LIBRI D, TAVITIAN B, DUCONGE F. Comparison of different strategies to select aptamers against a transmembrane protein target. Oligonucleotides. 2006; 16:323-335. [PubMed: 17155908]

RHODES A, DEAKIN A, SPAULL J, COOMBER B, AITKEN A, LIFE P, REES S. The generation and characterization of antagonist RNA aptamers to human oncostatin M. J Biol Chem. 2000; 275:28555-28561. [PubMed: 10882721]

RHODES A, SMITHERS N, CHAPMAN T, PARSONS S, REES S. The generation and characterisation of antagonist RNA aptamers to MCP-1. FEBS Lett. 2001; 506:85-90. [PubMed: 11591377]

SANTULLI-MAROTTO S, NAIR SK, RUSCONI C, SULLENGER B, GILBOA E. Multivalent RNA aptamers that inhibit CTLA-4 and enhance tumor immunity. Cancer Res. 2003; 63:7483-7489. [PubMed: 14612549] 
SHANGGUAN D, CAO Z, MENG L, MALLIKARATCHY P, SEFAH K, WANG H, LI Y, TAN W. Cell-Specific Aptamer Probes for Membrane Protein Elucidation in Cancer Cells. J Proteome Res. 2008a

SHANGGUAN D, MENG L, CAO ZC, XIAO Z, FANG X, LI Y, CARDONA D, WITEK RP, LIU C, TAN W. Identification of liver cancer-specific aptamers using whole live cells. Anal Chem. 2008b; 80:721-728. [PubMed: 18177018]

SHARPE AH, FREEMAN GJ. The B7-CD28 superfamily. Nat Rev Immunol. 2002; 2:116-126. [PubMed: 11910893]

SMITH JE, MEDLEY CD, TANG Z, SHANGGUAN D, LOFTON C, TAN W. Aptamer-conjugated nanoparticles for the collection and detection of multiple cancer cells. Anal Chem. 2007; 79:30753082. [PubMed: 17348633]

SULLENGER BA, GALLARDO HF, UNGERS GE, GILBOA E. Overexpression of TAR sequences renders cells resistant to human immunodeficiency virus replication. Cell. 1990; 63:601-608. [PubMed: 2225067]

TAKEDA K, KAISHO T, AKIRA S. Toll-like receptors. Annu Rev Immunol. 2003; 21:335-376. [PubMed: 12524386]

TSAI DE, KEENE JD. In vitro selection of RNA epitopes using autoimmune patient serum. J Immunol. 1993; 150:1137-1145. [PubMed: 7678618]

TSAI DE, KENAN DJ, KEENE JD. In vitro selection of an RNA epitope immunologically crossreactive with a peptide. Proc Natl Acad Sci U S A. 1992; 89:8864-8868. [PubMed: 1384035]

TUERK C, GOLD L. Systematic evolution of ligands by exponential enrichment: RNA ligands to bacteriophage T4 DNA polymerase. Science. 1990; 249:505-510. [PubMed: 2200121]

WATANABE T, ITO K, MATSUMOTO M, SEYA T, NISHIKAWA S, HASEGAWA T, FUKUDA K. Isolation of RNA aptamers against human Toll-like receptor 3 ectodomain. Nucleic Acids Symp Ser (Oxf). 2006:251-252.

WIEGAND TW, WILLIAMS PB, DRESKIN SC, JOUVIN MH, KINET JP, TASSET D. Highaffinity oligonucleotide ligands to human IgE inhibit binding to Fc epsilon receptor I. J Immunol. 1996; 157:221-230. [PubMed: 8683119] 
Table 1

Targeting tumor markers with aptamers

\begin{tabular}{|c|c|c|c|c|}
\hline Target & Reference & Reactivity & Chemistry & Application \\
\hline MUC-1 & (Ferreira et al., 2006) & Human & ssDNA & $\begin{array}{l}\text { Binding/Ab competition (Ferreira et al., } \\
\text { 2006) } \\
\text { Imaging (Borbas et al., 2007) }\end{array}$ \\
\hline PSMA & (Lupold et al., 2002) & Human & $2^{\prime} \mathrm{F}$ Pyrimidine RNA & $\begin{array}{l}\text { Antagonist (Lupold et al., 2002) } \\
\text { siRNA delivery (Chu et al., 2006c; } \\
\text { McNamara et al., 2006) } \\
\text { Toxin delivery (Chu et al., 2006a) } \\
\text { Imaging (Chu et al., 2006b; Smith et al., } \\
\text { 2007) } \\
\text { Nanoparticle targeting (Farokhzad et al., } \\
\text { 2004; Farokhzad et al., 2006; Gu et al., } \\
\text { 2008) }\end{array}$ \\
\hline Tenascin-C & (Hicke et al., 2001) & Human/Murine & $2^{\prime} \mathrm{F}$ Pyrimidine RNA & Imaging (Hicke et al., 2006) \\
\hline Tenascin-C & (Daniels et al., 2003) & Human & ssDNA & \\
\hline $\begin{array}{l}\text { Human epidermal } \\
\text { growth factor } \\
\text { receptor-3 (HER3) }\end{array}$ & (Chen et al., 2003) & Human & RNA & Antagonist \\
\hline $\begin{array}{l}\text { Receptor tyrosine } \\
\text { kinase (RET) } \\
\text { mutant RET }{ }^{\mathrm{C} 634 \mathrm{Y}}\end{array}$ & $\begin{array}{l}\text { (Cerchia et al., 2005; } \\
\text { Pestourie et al., 2006) }\end{array}$ & Human & $\begin{array}{l}2^{\prime} \mathrm{F} \text { Pyrimidine } \\
\text { Antagonist RNA }\end{array}$ & \\
\hline
\end{tabular}


Table 2

Aptamers to Antibodies

\begin{tabular}{|c|c|c|c|}
\hline Target & Reference & Chemistry & Application \\
\hline $\operatorname{IgE}$ & (Wiegand et al., 1996) & $2^{\prime}$ NH2 Pyrimidine RNA & $\begin{array}{l}\text { Antagonist (Wiegand et al., } \\
\text { 1996) } \\
\text { Aptamer array (Cho et al., } \\
2006 \text { ) } \\
\text { AFM microscopy (Lin et al., } \\
2006)\end{array}$ \\
\hline $\begin{array}{l}\text { Actylcholine receptor antibody } \\
\text { (mAB198) }\end{array}$ & $\begin{array}{l}\text { (Lee and Sullenger, 1997; Hwang } \\
\text { and Lee, 2002) }\end{array}$ & $2^{\prime}$ NH2 Pyrimidine RNA & Antagonist \\
\hline Insulin receptor antibody (MA20) & (Doudna et al., 1995) & RNA & Antagonist \\
\hline Insulin receptor antibody (MA20) & (Lee and Sullenger, 1996) & $2^{\prime} \mathrm{NH} 2$ Pyrimidine RNA & Antagonist \\
\hline Polyclonal Antibody & (Tsai et al., 1992) & RNA & Antagonist \\
\hline Autoimmune patient serum & (Tsai and Keene, 1993) & RNA & Antagonist \\
\hline
\end{tabular}

Hum Gene Ther. Author manuscript; available in PMC 2013 March 14. 
Table 3

Aptamers targeting cvtokines \& chemokines

\begin{tabular}{|c|c|c|c|c|}
\hline Target & Reference & Reactivity & Chemistry & Application \\
\hline Interferon $\gamma(\mathrm{IFN} \gamma)$ & (Kubik et al., 1997) & Human & $2^{\prime} \mathrm{NH} 2 / \mathrm{F}$ Pyrimidine RNA & Antagonist \\
\hline $\begin{array}{l}\text { Transforming growth factor } \beta-1 \\
\text { (TGF } \beta-1)\end{array}$ & (Kang et al., 2008) & Human & Ss phosphorothioate DNA & n.d. \\
\hline $\begin{array}{l}\text { Transforming growth factor } \beta-2 \\
\text { (TGF } \beta-2)\end{array}$ & (Pagratis et al., 2002) & Human & $2^{\prime} \mathrm{F} / \mathrm{OMe} \mathrm{RNA}$ & Antagonist \\
\hline CXCL10 & (Marro et al., 2005) & Human/Murine & $2^{\prime}$ Pyrimidine RNA & Antagonist \\
\hline Oncostatin M (OSM) & $\begin{array}{l}0 \text { (Rhodes et al., 2000; Rhodes et al., } \\
\text { 2001) }\end{array}$ & Human & $2^{\prime}$ F Pyrimidine RNA & Antagonist \\
\hline $\begin{array}{l}\text { Monocyte chemoattractant protein-1 } \\
\text { (MCP-1) }\end{array}$ & (Rhodes et al., 2001) & Murine/Human & $2^{\prime}$ F Pyrimidine RNA & Antagonist \\
\hline
\end{tabular}

Hum Gene Ther. Author manuscript; available in PMC 2013 March 14. 
Table 4

Adhesion molecules

\begin{tabular}{lllll}
\hline Target & Reference & Reactivity & Chemistry & Application \\
L Selectin & (Hicke et al., 1996) & Human & ssDNA & Antagonist (in vivo) \\
Sialyl Lewis X & (Jeong et al., 2001) & n/a & RNA & Antagonist \\
P Selectin & (Jenison et al., 1998) & Human & $2^{\prime}$ F Pyrimidine RNA & Antagonist \\
VCAM-1 & (Chauveau et al., 2007) & Mouse & $2^{\prime}$ F Pyrimidine RNA & Binding \\
\hline
\end{tabular}


Table 5

Costimulatorv receptors

\begin{tabular}{|c|c|c|c|c|}
\hline Target & Reference & Reactivity & Chemistry & Application \\
\hline $\begin{array}{l}\text { Cytotoxic T cell antigen- } 4 \\
\text { (CTLA-4) }\end{array}$ & $\begin{array}{l}\text { (Santulli-Marotto et al., } \\
\text { 2003) }\end{array}$ & Murine & $2^{\prime}$ F Pyrimidine RNA & Antagonist (in vivo) \\
\hline CD4 & (Kraus et al., 1998) & Rat & $2^{\prime}$ F Pyrimidine RNA & Antagonist \\
\hline CD4 & (Davis et al., 1998) & Human & $2^{\prime} \mathrm{F}$ Pyrimidine RNA & $\begin{array}{l}\text { Flow cytometry (Davis et al., } \\
\text { 1998) } \\
\text { siRNA delivery (Guo et al., } \\
\text { 2005) }\end{array}$ \\
\hline $\begin{array}{l}\text { Receptor Activator of NFkB } \\
\text { (RANK), CD30. TRAIL-R2, } \\
\text { NGFR, \& Osteoprotegerin }\end{array}$ & (Mori et al., 2004) & Human & $\begin{array}{l}\text { RNA ( } 2^{\prime} \text { F Pyrimidine } \\
\text { RNA) }\end{array}$ & \\
\hline $\begin{array}{l}\text { Transforming growth factor- } \\
\text { beta type III receptor (TGF } \beta \text { R } \\
\text { III) }\end{array}$ & (Ohuchi et al., 2006) & Human & $2^{\prime}$ F Pyrimidine RNA & Antagonist \\
\hline 4-1 BB & (McNamara et al., 2008) & Murine/Human & $2^{\prime}$ F Pyrimidine RNA & $\begin{array}{l}\text { Flow cytometry Agonist (in } \\
\text { vivo) (McNamara et al., 2008) }\end{array}$ \\
\hline
\end{tabular}

